\title{
Determination and Comparison of Physical and Physiological Characteristics of Football Players in the U10-17 Categories
}

\author{
Ömercan Göksu' ${ }^{1}$, Selami Yüksek ${ }^{2}$ \\ ${ }^{1}$ İstanbul Üniversitesi Beden Eğitimi ve Spor Yüksekokulu, Turkey \\ ${ }^{2}$ Karadeniz Teknik Üniversitesi Beden Eğitimi ve Spor Yüksekokulu, Turkey \\ Correspondence: Selami Yüksek, Karadeniz Teknik Üniversitesi Beden Eğitimi ve Spor Yüksekokulu, Turkey.
}

Received: February 11, 2018

doi:10.11114/jets.v6i4.3009
Accepted: March 6, $2018 \quad$ Online Published: March 18, 2018

URL: https://doi.org/10.11114/jets.v6i4.3009

\begin{abstract}
This study was conducted to determine some motoric characteristics of children football players in the 10-17 age group and to compare them according to their playing positions.

The study was carried out with voluntary participation of a total of 190 licensed athletes in Turkey Football Federation "U" category playing in Çeliktepe, Aslantepe and Seyrantepe sports club (U10-U17).

The athletes participated in the study were divided into the 10-13 and 14-17 age categories, and further divided into three groups, namely defensive, midfield and forward player groups according to their playing positions. Demographic information about the age, football sports age and playing positions of the athletes were recorded. The research measurements were made during the first week of the preparatory period at the start of the season. All participants were subjected to motoric tests that measure speed, agility, horizontal jump, endurance and balance parameters, which are considered important for football branch. In the analysis of the data, the SPSS 23.0 statistical program was used. The Kolmogorov Smirmov test was used to determine whether the data showed normal distribution, and "One-Way ANOVA", followed by "Tukey HSD" were used for the parameters with normal distribution, whereas "Kruskal-Wallis" and "Mann-Whitney U" test were used for the data with non-normal distribution; and $p<0.05$ was accepted as the level of significance.

As a result of the analysis of the data, there were statistically significant differences between motoric test results in term of the playing positions of football players $(\mathrm{p}<0.05)$.

As a result, it was determined that some of the motoric performance differences, prominent in early periods among football players playing in different positions, decrease in the following years due to age, training and experience factors and that all football players in all positions have similar motoric performances in today's football. Thus, it can be said that it is important for players to have similar motoric parameters in the sense that they can compete with each other, considering that the players playing in different positions (forward-defense, etc.) come across during competitions.
\end{abstract}

Keywords: football, children, playing position, performance, motoric tests

\section{Introduction}

Football is undoubtedly the most widespread and popular sport in the world. Having a large playing field, higher number of players and its challenging nature are some of the features that makes it special. These properties distinguish it physically and physiologically from other branches. In addition, the playing positions of football players in the field require them to undertake different roles and therefore it becomes a necessity to identify and assess their physical or physiological needs according to their playing positions.

Football game is a sports branch where strength, speed, endurance, agility and coordination skills are of extremely necessity. In addition to sudden accelerations, decelerations, difficult skills and jumps requiring balance and jumps, football players are expected to show a performance same as the first minutes of the game for 90 minutes. Therefore, a team having players with advanced motor skills and a high level of endurance is the team closest to winning. The game of football is a sports branch where all the motor skills are of extremely importance. For instance, no matter how talented an athlete is, it is not likely to benefit from the athlete's abilities if he/she gets tired early and recovers late. 
Getting tired early and recovering late is due to low aerobic capacity of the athlete. Therefore, players' ability to exhibit all of their performance skills for $90 \mathrm{~min}$. is limited by their aerobic power and capacities (Eniseler, 2010, Bompa \& Haff, 2015, Muratl1, Kalyoncu, \& Şahin, 2011).

Observation and analysis of football is important in terms of identifying its physical and physiological needs. The athletes can be trained or individuals suitable for the needs can be selected according to the results of the analysis. Directing football training and developing a football specific training is only possible with the necessary observation and analysis (Reilly, 2005). With an analysis of a football game, various movements such as walking, running, sprinting, backward or lateral running, jumping, or changing direction can be observed (Reilly, 1997, Mohr, Krustrup, \& Bangsbo, 2003, Reilly, 2006). This mobility, exhibited throughout the game, has parallels with the motoric performance level.

It is known that elite football players cover 10-12 km of distance on average in 90 minutes of football game and that they have very versatile movement series, which requires power, speed, endurance, agility and coordination skills. Moreover, football game is developing every day with the influence of the advances in training sciences and requires a match at a higher pace. For example, considering the distances covered by football players in the UK Premier League before the 1992 season and during the 1999-2000 season, it was found that there was a $1.5 \mathrm{~km}$ increase in the average distance covered during this period (Strudwick \& Reilly, 2001).

With this study, it was aimed to determine the position-based necessities of football game, which demands increasingly higher performances, as well as determining the characteristics of football players appropriate for the playing positions and developing the most appropriate training programs for football. Therefore, the aim of this study is to investigate the motoric skills of football players according to their playing positions and to determine the potential differences between the positions.

\section{Method}

\subsection{Study Group}

The study was conducted with voluntary participation of 190 licensed football players in the "U" category (U10-U17) registered in Turkey Football Federation Aslantepe, Çeliktepe and Seyrantepe Sports clubs, in accordance with the written permission and approval of their parents, in line with the Declaration of Helsinki principles (World Medical Association, 2008). The athletes participated in the study were divided into three groups, namely defensive, midfield and offensive players in the 10-13 and 14-17 age categories. In order to ensure data homogeneity, goalkeepers were included in the defensive players group together with defensive players. Demographic information about the age, football sports age and playing positions of the athletes were recorded.

\subsection{Data Collection}

All the research measurements were made during the first week of the preparatory period at the start of the season between the hours 10 and 17, in which there were no competitions, in the Istanbul Kağtthane Municipality Seyrantepe Football Stadium.

In determining the significance of the statistical differences between football players' playing positions and the motoric test results, One-Way ANOVA followed by "Tukey HSD" were used for the data with normal distribution (height, BMI, 10-30 meters sprint, Proagility 1st-2nd turn, 20 meter shuttle run in the 10-13 age group, and BMI in the 14-17 age group); and, "Kruskal-Wallis" followed by "Mann-Whitney U test" were used for the data with non-normal distribution (age, body weight, sports age, balance, horizontal jump in the 10-13 age group, and age, height, body weight, sports age, balance, horizontal jump, 10-30 meters sprint, Proagility 1st-2nd turn, 20 meter shuttle run in the 14-17 age group). The mean values and standard deviations of the parameters to be measured of all participants were calculated.

\section{Results}

This section presents the demographic information and findings of motoric test measurement and comparison analysis of 190 surveyed athletes divided into in the 10- 13 and 14--17 age groups., 
Table 1. Physical and demographic characteristics of the study group

\begin{tabular}{|c|c|c|c|c|c|c|c|c|c|}
\hline \multirow{2}{*}{\multicolumn{2}{|c|}{ Parameters }} & \multicolumn{4}{|c|}{$10-13$ age group } & \multicolumn{4}{|c|}{ 14-17 age group } \\
\hline & & \multirow{2}{*}{$\begin{array}{l}\mathrm{n} \\
27\end{array}$} & \multirow{2}{*}{$\begin{array}{l}X \pm S D \\
11.96 \pm 1.02\end{array}$} & \multirow{5}{*}{$\begin{array}{l}\mathrm{p} \\
\mathbf{0 . 0 0 6 * *}\end{array}$} & \multirow{5}{*}{$\begin{array}{l}\text { Significant } \\
\text { Difference } \\
\\
\text { D-F } \\
\text { M-F }\end{array}$} & \multirow{2}{*}{\begin{tabular}{|l|}
$\mathrm{n}$ \\
49
\end{tabular}} & \multirow{2}{*}{$\begin{array}{l}\mathrm{X} \pm \mathrm{SD} . \\
15.31 \pm 0.96\end{array}$} & \multirow{4}{*}{$\begin{array}{l}\mathrm{p} \\
0.982\end{array}$} & $\begin{array}{l}\text { Significant } \\
\text { Difference }\end{array}$ \\
\hline \multirow{4}{*}{ Age (years) } & $\mathrm{D}$ & & & & & & & & \\
\hline & $\mathrm{M}$ & 16 & $12.38 \pm 0.89$ & & & 33 & $15.30 \pm 1.02$ & & \\
\hline & $\mathrm{F}$ & 33 & $11.33 \pm 1.16$ & & & 32 & $15.28 \pm 0.99$ & & \\
\hline & $\mathrm{T}$ & 76 & $11.78 \pm 1.13$ & & & 114 & $15.30 \pm 0.98$ & & \\
\hline \multirow{4}{*}{ Height (cm) } & $\mathrm{D}$ & 27 & $151.33 \pm 10.79$ & \multirow{4}{*}{0.213} & & 49 & $168.90 \pm 9.86$ & \multirow{4}{*}{$0.019 *$} & \multirow{4}{*}{ D-M } \\
\hline & $\mathrm{M}$ & 16 & $150.06 \pm 8.81$ & & & 33 & $163.42 \pm 9.5$ & & \\
\hline & $\mathrm{F}$ & 33 & $146.67 \pm 10.87$ & & & 32 & $166.47 \pm 10.48$ & & \\
\hline & $\mathrm{T}$ & 76 & $149.04 \pm 10.53$ & & & 114 & $166.63 \pm 10.11$ & & \\
\hline \multirow{4}{*}{$\begin{array}{l}\text { Body Weight } \\
\text { (kg) }\end{array}$} & $\mathrm{D}$ & 27 & $41.89 \pm 8.14$ & \multirow{4}{*}{0.451} & & 49 & $58.92 \pm 10.06$ & \multirow{4}{*}{0.174} & \\
\hline & $\mathrm{M}$ & 16 & $42.19 \pm 7.30$ & & & 33 & $54.12 \pm 11.13$ & & \\
\hline & $\mathrm{F}$ & 33 & $39.88 \pm 8.37$ & & & 32 & $57.75 \pm 10.50$ & & \\
\hline & $\mathrm{T}$ & 76 & $41.08 \pm 8.04$ & & & 114 & $57.20 \pm 10.60$ & & \\
\hline \multirow{4}{*}{ BMI $\left(\mathrm{kg} / \mathrm{m}^{2}\right)$} & $\mathrm{D}$ & 27 & $18.15 \pm 1.83$ & \multirow{4}{*}{0.758} & & 49 & $20.53 \pm 2.15$ & \multirow{4}{*}{0.450} & \\
\hline & $\mathrm{M}$ & 16 & $18.61 \pm 1.80$ & & & 33 & $20.03 \pm 2.23$ & & \\
\hline & $\mathrm{F}$ & 33 & $18.38 \pm 2.19$ & & & 32 & $20.65 \pm 2.06$ & & \\
\hline & $\mathrm{T}$ & 76 & $18.34 \pm 1.97$ & & & 114 & $20.42 \pm 2.14$ & & \\
\hline \multirow{4}{*}{$\begin{array}{l}\text { Sports } \\
\text { (years) }\end{array}$} & $\mathrm{D}$ & 27 & $3.26 \pm 1.46$ & \multirow{4}{*}{$0.017 *$} & \multirow{4}{*}{$\mathrm{M}-\mathrm{F}$} & 49 & $5.04 \pm 2.29$ & \multirow{4}{*}{0.216} & \\
\hline & $\mathrm{M}$ & 16 & $4.13 \pm 1.36$ & & & 33 & $5.73 \pm 2.07$ & & \\
\hline & $\mathrm{F}$ & 33 & $2.82 \pm 1.81$ & & & 32 & $5.78 \pm 2.28$ & & \\
\hline & $\mathrm{T}$ & 76 & $3.25 \pm 1.66$ & & & 114 & $5.45 \pm 2.23$ & & \\
\hline
\end{tabular}

$* \mathrm{p}<0.05 ; * * \mathrm{p}<0.01$; D: Defense; M: Midfield; F: Forward; T: Total

According to the statistical evaluation, differences between evaluation results and age and sports age in 10-13 age group and height in the 14-17 age group were found to be statistically significant, whereas the differences between the other measurement results were not statistically significant (Table 1).

Table 2. Motoric test measurement results of the participants

\begin{tabular}{|c|c|c|c|c|c|c|c|c|c|}
\hline \multirow{2}{*}{\multicolumn{2}{|c|}{ Parameters }} & \multicolumn{4}{|c|}{$10-13$ age group } & \multicolumn{4}{|c|}{ 14-17 age group } \\
\hline & & $\mathrm{n}$ & $\mathrm{X} \pm \mathrm{SD}$ & $\mathrm{p}$ & $\begin{array}{l}\text { Significant } \\
\text { Difference }\end{array}$ & $\mathrm{n}$ & $\mathrm{X} \pm \mathrm{SD}$ & $\mathrm{p}$ & Significant Difference \\
\hline \multirow{4}{*}{ Balance (Min/Count) } & $\mathrm{D}$ & 27 & $5.78 \pm 1.99$ & \multirow{4}{*}{0.56} & & 49 & $3.84 \pm 1.55$ & \multirow{4}{*}{0.469} & \\
\hline & $\mathrm{M}$ & 16 & $5.25 \pm 2.27$ & & & 33 & $4.03 \pm 1.42$ & & \\
\hline & $\mathrm{F}$ & 33 & $5.76 \pm 2.15$ & & & 32 & $3.63 \pm 1.68$ & & \\
\hline & $\mathrm{T}$ & 76 & $5.66 \pm 2.10$ & & & 114 & $3.83 \pm 1.55$ & & \\
\hline \multirow{5}{*}{ Horizontal Jump (m) } & $\mathrm{D}$ & 27 & $151.37 \pm 29.33$ & \multirow{5}{*}{ 0.018* } & \multirow{5}{*}{$\begin{array}{l}\text { D-F } \\
\text { M-F }\end{array}$} & 49 & $199.04 \pm 24.99$ & \multirow{5}{*}{0.123} & \\
\hline & $\mathrm{M}$ & 16 & $157.63 \pm 27.26$ & & & 33 & $194.18 \pm 23.81$ & & \\
\hline & \multirow{2}{*}{$\mathrm{F}$} & \multirow{2}{*}{33} & $134.88 \pm 23.51$ & & & 32 & $205.22 \pm 29.39$ & & \\
\hline & & & $14553+2786$ & & & \multirow{2}{*}{114} & $199.37 \pm 26.08$ & & \\
\hline & & 10 & $10.03-2.00$ & & & & & & \\
\hline \multirow{4}{*}{ Sprint 10 m (Sec.) } & $\mathrm{D}$ & 27 & $2.14 \pm 0.21$ & \multirow{4}{*}{0.119} & & 49 & $1.93 \pm 0.13$ & \multirow{4}{*}{0.273} & \\
\hline & $\mathrm{M}$ & 16 & $2.08 \pm 0.12$ & & & 33 & $1.94 \pm 0.12$ & & \\
\hline & $\mathrm{F}$ & 33 & $2.18 \pm 0.12$ & & & 32 & $1.90 \pm 0.13$ & & \\
\hline & $\mathrm{T}$ & 76 & $2.15 \pm 0.16$ & & & 114 & $1.92 \pm 0.13$ & & \\
\hline \multirow{4}{*}{ Sprint $30 \mathrm{~m}$ (Sec.) } & $\mathrm{D}$ & 27 & $5.33 \pm 0.59$ & \multirow{4}{*}{0.095} & & 49 & $4.69 \pm 0.40$ & \multirow{4}{*}{0.306} & \\
\hline & $\mathrm{M}$ & 16 & $5.14 \pm 0.39$ & & & 33 & $4.70 \pm 0.36$ & & \\
\hline & $\mathrm{F}$ & 33 & $5.44 \pm 0.34$ & & & 32 & $4.59 \pm 0.38$ & & \\
\hline & $\mathrm{T}$ & 76 & $5.34 \pm 0.46$ & & & 114 & $4.66 \pm 0.38$ & & \\
\hline \multirow{4}{*}{ Proagility 1st Turn (Sec.) } & $\mathrm{D}$ & 27 & $3.09 \pm 0.28$ & \multirow{4}{*}{$0.001 * *$} & \multirow{4}{*}{$\begin{array}{l}\text { D-F } \\
\text { M-F }\end{array}$} & 49 & $2.77 \pm 0.21$ & & \\
\hline & $\mathrm{M}$ & 16 & $3.06 \pm 0.25$ & & & 33 & $2.79 \pm 0.20$ & 0254 & \\
\hline & $\mathrm{F}$ & 33 & $3.32 \pm 0.25$ & & & 32 & $2.73 \pm 0.25$ & 0.254 & \\
\hline & $\mathrm{T}$ & 76 & $3.18 \pm 0.28$ & & & 114 & $2.76 \pm 0.22$ & & \\
\hline & $\mathrm{D}$ & 27 & $5.99 \pm 0.54$ & & & 49 & $5.36 \pm 0.41$ & & \\
\hline Droogility 2nd Turn (Cor) & $\mathrm{M}$ & 16 & $5.88 \pm 0.46$ & $0007 * *$ & D-F & 33 & $5.36 \pm 0.35$ & 0220 & \\
\hline Proagillty zna iurn (sec.) & $\mathrm{F}$ & 33 & $6.35 \pm 0.56$ & $0.00 / \cdots$ & M-F & 32 & $5.26 \pm 0.42$ & 0.329 & \\
\hline & $\mathrm{T}$ & 76 & $6.12 \pm 0.57$ & & & 114 & $5.33 \pm 0.39$ & & \\
\hline & D & 27 & $1125.19 \pm 435.24$ & & & 49 & $1704.08 \pm 506.77$ & & \\
\hline & M & 16 & $1340 \pm 375.09$ & & & 33 & $1835.76 \pm 437.77$ & & \\
\hline Shuttle Run (m) & & & & $0.007 * *$ & M-F & & $1917.50 \pm 374.47$ & 0.209 & \\
\hline & $\mathrm{F}$ & 33 & $951.52 \pm 375.47$ & & & 32 & & & \\
\hline & $\mathrm{T}$ & 76 & $1095 \pm 419.7$ & & & 114 & $1802.11 \pm 458.36$ & & \\
\hline
\end{tabular}

$* \mathrm{p}<0.05 ; * * \mathrm{p}<0.01 ;$ D: Defense; M: Midfield; F: Forward; T: Total 
According to the statistical analysis, it was found that the difference between the results of horizontal jump, proagility sprint and $20 \mathrm{~m}$ shuttle run endurance test results of 10-13 age group football players was statistically significant in terms of their playing positions, but the difference between the other measurement results was not significant ( $p>0.05$ ). For the 14-17 age group football players, however, it was found that the differences between the motoric measurement results were not significant in terms of their playing positions (Table 2).

\section{Discussion and Conclusion}

In all sport branches, the goal is to achieve success. A growing number of scientific studies affect sporting success in Turkey in a positive way. Studies revealed that the physical characteristics of the body showed differences among the different categories of the same sports branch. This study aims to investigate whether some motoric skills and capacities of 10-17-year-old football players differ according to their playing positions. The data obtained are very important in determining the roles to be assumed by the athletes, assigning them to the positions where they will be able to exert the best performance or preparing training plans and programs suitable for their playing positions in accordance with their characteristics (Gil, Gil, Ruiz, Irazusta, \& Irazusta, 2007).

The test results showed that defense players were older than forward players, and midfield players were older than forward players in terms of the age parameter, whereas midfield players' sports age parameters were greater than the forward players in the 10-13 age category. In the 14-17 age group, however, the defense players were longer than the midfield players, whereas the athletes in both age categories were similar in terms of other parameters (Table 1).

Test results showed that the performance of the athletes in the flamingo balance test did not differ according to their playing positions in both age groups and that the athletes had a similar balance skills ( $p>0.05)$. In their study conducted with 72 amateur football players playing in four different leagues, Kartal, Kartal and Irez (2016) reported that there was no significant difference between the balance performances of the players in terms of their playing positions, and also reported that the players had a similar balance skill.

The test results showed that both the defense players and the midfield players performed better than the forward players $(p<0.05)$ in the 10-13 age group in the horizontal jump test, whereas in the other positions and in the 14-17 age category the athletes had a similar jump performance ( $p>0.05)$. In their study conducted with 36 elite football players, Yapıc1 et al. (2016) reported that there was no statistically significant difference between the horizontal jump performance of the athletes in terms of their position and that the athletes had a similar jump skill. Similarly, Kizılet et al. (2004) reported in their study carried out with 63 elite football players that there was no significant difference between their playing positions and horizontal jump performances and that the athletes had a similar jump performance.

Test results showed that the performance of the athletes in the $10 \mathrm{~m}$ and $30 \mathrm{~m}$ sprint test did not differ according to their playing positions in both age groups and that the athletes had similar sprint skills ( $p>0.05)$. Kartal, Kartal and Irez (2016) reported that football players' speed performances did not differ according to their playing positions, and that players in different positions had similar speed skills. Similarly, in his research with 154 elite football players, Taşkın (2006) reported that there was no statistically significant difference in the speed performances of the athletes according to their playing positions. In a different study, Aslan and Koç (2015) reported that the difference between the results of $10 \mathrm{~m}$ and $30 \mathrm{~m}$ sprint tests of the athletes in their study, conducted with 70 male athletes with training age of 5 and over, was not statistically significant and the athletes had similar speed skills. Similarly, in their study conducted with 69 football players, Malina et al. (2004) reported that the difference between the athletes' $30 \mathrm{~m}$ sprint scores was not statistically significant, and that the athletes have similar sprint skills. Likewise, in his study carried out with 152 football players, Sever (2013) reported that the difference between the athletes' sprint scores of $10 \mathrm{~m}$ and $30 \mathrm{~m}$ was not statistically significant $(\mathrm{p}>0.05)$. In their research conducted with 35 elite football players, Bostanc1 et al. (2004) reported that the anaerobic power values of the athletes did not differ according to their playing positions. Similarly, Güldal (2013), in his study with 32 elite football players, reported that the anaerobic power values of the athletes did not differ according to their playing positions. Since short-distance sprint performance is a sign of anaerobic power, the studies support our findings. In a different study with partially different outcomes, Yapıc1 et al. (2016) reported that the difference between the athletes' 10-m sprint ratings was not statistically significant ( $>0.05)$ in terms of their playing positions, but the difference between midfield and forward players' 30 -m sprint ratings was reported to be statistically significant in favor of midfield players. Kizilet et al. (2004) reported that forward players' sprint performances were higher than defensive players $(\mathrm{p}<0.05)$.

The test results showed that both the defense players and the midfield players performed better than the forward players $(\mathrm{p}<0.05)$ in the 10-13 age group in the agility test, whereas in the other positions and in the 14-17 age category the athletes had a similar agility performance ( $>0.05$ ). In his study conducted with 152 football players, Sever (2013) reported that there was no statistically significant difference between the agility performance scores of the players according to their playing positions ( $p>0.05$ ). In a different study, Yapıcı et al. (2016) reported a statistically significant 
difference between defense and midfield players' agility performances $(\mathrm{p}<0.05)$, but the agility skills of the athletes playing in other positions was reported to be similar $(p>0.05)$.

Test results showed that there was statistically significant difference between midfield players and forward players in terms of $20 \mathrm{~m}$ shuttle run aerobic power test in the 10-13 age group category in favor of midfield players ( $\mathrm{p}<0.05)$, but it was observed that athletes had similar endurance in other playing positions and in the 14-17 age category ( $\mathrm{p}>0.05)$. Kizilet et al. (2004) reported that the midfield players' $\mathrm{MaxVO}_{2}$ values were higher than the $\mathrm{MaxVO}_{2}$ values of the goalkeepers, forward players and defensive players. Similarly, based on the performance analysis of 300 elite football players, Di Salvo et al. (2007) reported that midfield players cover more distance in the game, and therefore have more advanced aerobic capacities. In addition, Sever (2013) found that aerobic capacities of midfield players were higher than aerobic capacities of football players playing in other positions. It was also reported in the same study that the aerobic capacity of the defensive players was higher than the aerobic capacity of the goalkeeper and forward players, and the aerobic capacity of the goalkeepers was higher than the aerobic capacity of the forward players. Aslan and Koç (2015) reported no statistically significant difference between aerobic capacities according to the positions of the athletes. Bostanc1 et al. (2004) reported that aerobic power values of midfield players were higher than average aerobic power values of defensive players. In the same study, it was also reported that the average aerobic power values of the goalkeepers were higher than the average aerobic power values of the defense and forward players. In their study carried out with 29 elite football players, Nilsson and Cardinale (2015) reported that average aerobic capacities of midfield players were higher than aerobic capacities of defensive and offensive players, but this difference has been reported to be not statistically significant. In addition, they reported that playing locations of football players caused no significant difference in aerobic power parameters. Similarly, Malina et al. (2004) reported that the aerobics capacities of football players did not vary according to their playing position. In addition, Yapıc1 et al. (2016) reported that football players playing at different positions have a similar aerobic capacity. In his study conducted with 32 elite football players, Güldal (2013) reported that there was no statistically significant difference between midfielder and defensive players, and defensive players and offensive players in terms of aerobic capacities.

As a result, in terms of basic motoric characteristics such as horizontal jump, agility and endurance in the children football players in the 10-17 age group in today's football, it was determined that some of the distinct motoric performance differences in early periods among football players playing in different positions decrease in the following years due to age, training and experience factors and that all football players in all positions have similar motoric performances. This can be regarded as a sign that the differences between the defensive, midfield and forward players in football game disappear in terms of physical and motoric characteristics, in parallel to the results of other studies in the literature. The main reason for the decrease in these differences is that today's football expects football players to offer additional contributions to the game, such as participation of defensive players in forward positions, or strikers coming to the defense for intercepting the ball as well as fulfilling their positional duties. It is believed that this new role distribution causes the motoric performance levels, such as the running distance of the players in the match, the sudden acceleration and deceleration, the direction changes, and the ability to maintain the body position in difficult positions, to approach each other regardless of position. Thus, it can be said that it is important for players to have similar motoric parameters in the sense that they can compete with each other, considering that the players playing in different positions (forward-defense, etc.) come across during competitions.

\section{References}

Aslan, C., \& Koç, H. (2015). Comparing Selected Physical and Motoric Characteristics of Turkish Amateur Soccer Players According to Playing Positions. CBU Journal of Physical Education and Sport Sciences, 10(1), 56-65.

Bompa, T. O., \& Haff, G. G. (2009). Periodization. Theory and methodology of training, 5th Edition, Human Kinetics.

Bostancı, Ö., Taşmektepligil, Y., \& Ayyıldız, M. (2004). Effects Of Preparatıon Period On Physical And Physiological Parameters Of Amateur Football Players. Gazi Journal Of Physical Education And Sports Sciences, 9(2), 43-58.

Di Salvo, V., Baron, R., Tschan, H., Montero, F., Bachl, N., \& Pigozzi, F. (2007). Performance Characteristics According to Playing Position in Elite Soccer. International journal of sports medicine, 28(3), 222-227. https://doi.org/10.1055/s-2006-924294

Eniseler, N. (2010). Bilimin Işığında Futbol Antrenmanı (1st ed.). Manisa: Birleşik Matbaacılık.

Gil, S., Gil, J., Ruiz, F., Irazusta, A., \& Irazusta, J. (2007). Physiological and anthropometric characteristics of young soccer players according to their playing position: relevance for the selection process. The Journal of Strength \& Conditioning Research, 21(2), 438-445. https://doi.org/10.1519/00124278-200705000-00026

Güldal, Y. (2013). Professional soccer players aerobic and anaerobic capacity of the relationship between the players position (Unpublished master's thesis). Kırıkkale University, Kırıkklale, Turkey. 
Kartal, A., Kartal, R., \& İrez, G. B. (2016). Investigate of Some Motor Functions According to Soccer Players Playing Positions. CBU Journal of Physical Education and Sport Sciences, 11(1), 55-62.

Kızılet, A., Erdem, K., Karagözoğlu, C., Topsakal, N., \& Çalışkan, E. (2004). Evaluation Of Some Physical And Physiological Profiles Of Soccer Players According To Playing Position. Gazi Journal Of Physical Education And Sports Sciences, 3, 67-78.

Malina, R. M., Eisenmann, J. C., Cumming, S. P., Ribeiro, B., \& Aroso, J. (2004). Maturity-associated variation in the growth and functional capacities of youth football (soccer) players 13-15 years. European Journal of Applied Physiology, 91(5-6), 555-556. https://doi.org/10.1007/s00421-003-0995-z

Mohr, M., Krustrup, P., \& Bangsbo, J. (2003). Match performance of high-standard soccer players with special reference to development of fatigue. Journal of Sports Sciences, 21(7), 519-528. https://doi.org/10.1080/0264041031000071182

Muratlı, S., Kalyoncu, O., \& Şahin, G. (2011). Antrenman ve Müsabaka. İstanbul: Kalyoncu Spor Danışmanlık San. Tic. Ltd. Şti.

Nilsson, J., \& Cardinale, D. (2015). Aerobic and anaerobic test performance among elite male football players in different team positions. LASE Journal of Sport Science, 6(2), 73-92.

Reilly, T. (1997). Energetics of high-intensity exercise (soccer) with particular reference to fatigue. Journal of Sports Sciences, 15(3), 257-263. https://doi.org/10.1080/026404197367263

Reilly, T. (2005). An ergonomics model of the soccer training process. Journal of sports sciences, 23(6), 561-572. https://doi.org/10.1080/02640410400021245

Reilly, T. (2006). The science of training-soccer: A scientific approach to developing strength, speed and endurance. New York: Routledge.

Sever, O. (2013). Investigation of physical fitness levels of soccer players according to position and age variables (Unpublished master's thesis). Gazi University, Ankara, Turkey.

Strudwick, T., \& Reilly, T. (2001). Work-rate profiles of elite Premier League football players. Insight, 2(2), 28-29.

Taşkın, H. (2006). Investigation Some Physical Parameters and 30 Meter Sprint Capabilities of Professional Soccer Players' According To Their Playing Positions. Spormetre Journal of Physical Education and Sport Sciences, 4(2), 49-54.

World Medical Association. (2008). Declaration of Helsinki-Ethical principles for medical research involving human subjects. Retrieved from

https://www.wma.net/policies-post/wma-declaration-of-helsinki-ethical-principles-for-medical-research-involvinghuman-subjects/

Yapıcı, A., Aydın, E., Çelik, E., \& Başkaya, G. (2016). The Comparison of Motoric Characteristics of Young Soccer Players According to Their Playing Positions. Sportive Sight: Journal of Sports and Education, 3(1), 49-60.

\section{Copyrights}

Copyright for this article is retained by the author(s), with first publication rights granted to the journal.

This is an open-access article distributed under the terms and conditions of the Creative Commons Attribution license which permits unrestricted use, distribution, and reproduction in any medium, provided the original work is properly cited. 